\title{
RESEARCH
}

\section{A comprehensive approach in developing akhlaq}

\section{A case study on the implementation of character education at Pondok Pesantren Darunnajah}

\section{Introduction}

Character (akhlaq) is internal states, traits, qualities or abilities that individuals' possess which lead them to perform the behavior without thought and deliberation and have developed into a habit whereas its values laid on the teachings of Islam. It includes both inward qualities and outward behavior of human; and it is based on the perspective that behaviors are closely related to the soul and its intention. Besides home, another significant factor in where character could be inculcated is school. Over the past three decades of scientific studies in the field of character development and character education, there are literatures related to the positive relationships of character education (Bauer, 1991; Berkowitz and Bier, 2005; Nucci and Narvaez, 2008;

Implementation of character education

\author{
Duna Izfanna \\ International Islamic University Malaysia, Kuala Lumpur, \\ Malaysia and \\ STAI Darunnajah, Jakarta, Indonesia, and \\ Nik Ahmad Hisyam \\ International Islamic University Malaysia, Kuala Lumpur, Malaysia
}

\begin{abstract}
Purpose - The purpose of this paper is to describe how a unique Islamic education system, named Pondok Pesantren, implemented and contributed substantially to the character education of its students.

Design/methodology/approach - In total, 12 teachers and 24 students of Pondok Pesantren Darunnajah, Indonesia were interviewed, participated in focus groups discussions, and were observed. Findings - Findings suggest that Pondok Pesantren Darunnajah adopts the comprehensive approach of character education which is laid on Islamic values as its ultimate philosophy. The majority of teachers and students reported that the Pondok Pesantren Darunnajah educates and develops students' character by infusing knowledge, providing supportive conditions or environment, then giving chances to practice and form.

Originality/value - The paper proposes a model of character education at Pondok Pesantren, as well as other Islamic education systems which have similar characteristics on the implementation of character education. Recommendations for future researches and practice are also presented.
\end{abstract}

Keywords Indonesia, Educational psychology, Schools, Islam, Character education, Pondok Pesantren, Islamic boarding school

Paper type Research paper

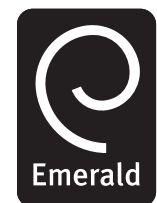

Multicultural Education \& Technology Journal Vol. 6 No. 2, 2012 pp. $77-86$

(c) Emerald Group Publishing Limited $1750-497 \mathrm{X}$ DOI $10.1108 / 17504971211236254$ 
METJ

6,2

78
Lickona et al., 2003; Chartier, 2007), influential factors contributing to the development of character on students (Bauer, 1991; Chartier, 2007; Ryan and Lickona, 1992). However, besides the growth in research into character education, the majority of studies focused on early and elementary education (Strom and Parsons, 1982; Power et al., 1989; Mosher et al., 1994; Higgins, 1995; Veugelers, 1997; Lockwood, 1997 as stated in Williams et al., 2003). In fact, although character education begun in early childhood, there is a need to extend and reinforce during the teenage years, a time period when various social behaviours become much more challenging.

In the past five years, character education has become a growing issue in Indonesia. For example, Indonesian Minister of National Education, Mohammad Nuh, at the grand opening of a national symposium on "the developing cultural education and character", stated that schools must be an essential agent in educating students' character (Hilda Sabri Sulistyo, 2010). He argued that the decreasing moral, ethics, and cultural values are due to the lack of character education, and so it is indicated the need for a re-evaluation of the school's role in teaching values and characters. According to Megawangi (2007), character education in Indonesia mostly remains a theory without any reflection from the teaching practice. Character and moral education such as Pancasila moral education (PMP), pendidikan kewarganegaraan (civic education) or Religious subject's do not succeed because although the subjects contain good lessons, they leave no trace in the humans' way of behaving. Ryan and Lickona (1992) affirms that character education must follow a process of knowing the good, loving the good, and acting the good and this needs to involve cognitive (mind), emotional (heart), and physical (hands) aspects of a person.

During the National Symposium on "Building national character" at the Educational University of Indonesia (UPI), the Vice Minister of National Education of Indonesia, Prof. Dr Fasli Jalal PhD suggested that Pondok Pesantren can be one of the references on the implementation of character education (Herdani, 2010). The present research explores the implementation of character education at Pondok Pesantren and its contribution to the character education of the students.

\section{Pondok Pesantren Darunnajah, Jakarta Indonesia}

Pondok derived from the Arabic word "funduq" and means humble house (Wehr, 1976) and by extension, it means Islamic religious boarding school (Denny, 1995). The term Pondok is used in Malaysia and Southern Thailand, whereas Pesantren is used most often in Indonesia, especially in Java, and sometimes the two terms are combined as "Pondok Pesantren", to clarify it is "a traditional Islamic boarding school and not merely a religious day school (such as the more modern madrasa)" (Denny, 1995, p. 296). However, the researcher suggests that Pondok, Pesantren, and Pondok Pesantren are synonymous (Abdullah Syukri Zarkasyi, 2005) and refers to Islamic educational institution that have a Pondok or boarding system where a Kyai or religious leader acts as a central Figure (as teacher, educator, and advisor), the mosque as the central element, and Islamic teaching that mould students' activities.

Pondok Pesantren can be found across the Islamic world and, although to some extent differ, are usually called "Pondok" in Malaysia and Southern Thailand and "madrasa Islamia" (madrasa) in India, Pakistan and most of the Arabic world. The pedagogical ideal of Pondok Pesantren includes intellectual as well as moral and character aspects in which the students are drawn ever closer to God as it is mentioned by Dhofier $(1985,1999)$ that: 
Education in a Pesantren does not seek [...] (only) to fill the minds of students with information, but to refine their morals, educate their spirits, propagate virtue, teach propriety, and prepare students for a life of sincerity and purity. Every student is taught to regard religious ethics above all else. The student's goal in education must not to obtain power, money, or glory; learning is an obligation, a dedication to God.

In its earlier development in Indonesia, Pondok Pesantren was traditionally taught in almost exclusively religious teaching and was the training grounds for religious leaders (Dhofier, 1985, 1999; Mastuhu, 1994; Anderson, 1990 as stated in Lukens-Bull, 2005). Today, it has been acknowledged as one of the educational institutions based on the National Educational System of Indonesia No. 20 article 302003 on the religious institution (Direktorat Pendidikan Nasional (Ministry of National Education), 2003) and it has become an increasingly popular choice for Indonesian parents over the last decade or more (Diknas, 2006 as cited in Direktorat Jenderal Pendidikan Islam, kementerian Agama RI Directorate General of Islamic Education, Ministry of Religious Affairs of Indonesia, 2009).

The Indonesia Minister of Education, Muhammad Nuh, as well as Mansyur Ramli, the Head of Research and Development Bureau at the National Ministry of Education, Komaruddin Hidayat, Rector of the State Islamic University (UIN), and also Amin Haedari, the President of Pondok Pesantren Association of Indonesia, acknowledged that Pondok Pesantren has been successfully implementing characters, such as honesty, social-awareness, leadership, brotherhood, modesty, generosity, and tolerant among the students, and those should be transferred to common schools (Annisa Mutia, 2010). Further, during the National Symposium on "Building national character" at the Educational University of Indonesia (UPI), the Vice Minister of National Education of Indonesia, Prof. Dr Fasli Jalal PhD also insisted the urgency of character education at schools as a strong foundation, and Pesantren can be one of the references on the implementation of character education whereby it is not only based on the formal curriculum, but also through awareness and habitual process (Herdani, 2010). Thus, the question raised is "how does Pondok Pesantren actually build students' character?" While there are a lot of studies related to Pondok Pesantren and a body of literature that discusses the importance of educating character at Pondok Pesantren (Dhofier, 1985, 1999; Abdullah Syukri Zarkasyi, 2005; Qomar, 2005; Direktorat Jenderal Pendidikan Islam, kementerian Agama RI Directorate General of Islamic Education, Ministry of Religious Affairs of Indonesia, 2009), there has been a lack of research specifically exploring the implementation of character education at Pondok Pesantren.

The context of the present study is Pondok Pesantren Darunnajah, a private Islamic boarding school in Indonesia. It integrates two educational systems: a formal educational system and a boarding school system (Pesantren system) that emphasizes on daily life education. This is to create a synergy in which both systems could be complementary to each other. The formal educational system is calles Tarbiatul Muallimin/at al-Islamiyah, a six year education, which is equivalent to junior (three years) and senior (three years) high school with state exam at the end of each level. Pondok Pesantren Darunnajah implement Islamic values in the school curriculum and within its environment which attempt to nurture character of students as well as to cultivate the sustenance and reproduction of knowledge. Based on the annual report of new students intake (Darunnajah, 2004-2009, 2010), the second main reasons given for parents sending their children in Pondok Pesantren are a desire for their children

\section{Implementation of character education}


METJ

6,2

80 to be educated in both science and religious knowledge, good discipline, and the adoption of Muslim character (akhlakul karimah).

\section{Character education}

Character in Arabic relates to the term khuluq (plural: akhlaq). The importance of character has been affirmed since the beginning of Islam. Prophet Muhammad is believed by Muslims to have been given the best of character as stated in the Qur'an. The Quran states "surely, you (Muhammad) have a sublime character" (al-Qur'an 68: 4). Many Muslim scholars have studied character, among them are al-Farabi (d. 950), Miskawayh (d. 1030), al-Ghazali (d. 1111), Fakhr al-Din al-Razi (d. 1209), al-Tusi (d. 1274), and al-Dawwani (d. 1502) (Omar, 2003). According to Maskawayh and al-Ghazali character is an established state of the soul from which action proceeds. Al-Ghazali emphasizes that character is comprehensive and covers every aspect of human life and for Muslims this is guided by the Qur'an and Hadiths:

A good (character) man is wise, courageous and temperate in the noblest sense of the words, and in the highest degree. He engages in worship, prayers, fasting, alms-giving, and similar acts, but his duties to God do not exclude his duties to family, relatives, friends, neighbours, slaves, subjects and society as a whole [...] And the motive force behind a perfect life is nothing other than the love and fear of God.

In addition, character is developed in stages (Ahmed, 1970). First, it is based on knowledge to know what is right or wrong and our responsibility as an individual (fardhu 'ain) and as part of the society (fardhu kifayah. Second, identify correct actions and perceived truth behind action. Third, identify knowledge and understandings of our actions and sustain our practice ('azm). Finally, our practice needs to be the embodiment of exemplary behaviour ('amal sholeh).

The present study is focused on character education to support students follow the way of the Quran. Some authors such as Bauer (1991), Ryan and Lickona (1992), Huitt (2000), and Berkowitz (2005) use the term character education and character building simultaneously. Most of the literatures and previous researches on character education discuss on certain curriculum, instruction, program or workshop designed exclusively on teaching character in schools. However, there is one approach of character education argues that the best way to implement character education is by integrating character development in every aspect of school life, for example through direct instruction, modelling, reinforcement, and various community-building strategies when and where appropriate, and then encourage students put their thoughts and feelings into action in a variety of school activities (Berkowitz, 1995 as cited in Huitt, 2000; Bauer, 1991; Berkowitz, 2005). The paper employs this approach as the framework of the present study and defines character education as a continuous process of and deliberate effort of school in developing good character of students through every aspects of school life.

\section{Research design}

The study uses a case study approach to research design to explore the implementation of character education at Pondok Pesantren Darunnajah. A total of 12 senior teachers of the Pondok Pesantren provided access and supporting information in support of the study. The teachers were interviewed and they provided their views and experiences about 
character education at Pondok Pesantren Darunnajah. In addition focus group interviews were also conducted with 24 students in both junior and senior high school. In addition, the researcher also carried out extensive observations for six months in 2011.
Implementation

of character education

\section{Results}

The researcher discusses the findings in the context of the following:

- the philosophy of character education;

- the process of implementation; and

- factors influencing the implementation of character education at Pondok Pesantren Darunnajah.

\section{The philosophy of character education}

Most of the teachers and students involved in this study have an Islamic understanding of character as being associated with psychological states, traits, or attitudes of a person which have inculcated and developed into behaviour. From the interview responses, it was found that Pondok Pesantren Darunnajah develops student character based on Islamic values and this is implemented in many ways through character education.

All the interviewed teachers and students affirm the importance of character education and mention that the philosophy of character education at Pondok Pesantren Darunnajah states its vision and mission which is to "to build virtuous Muslim and Islamic society by providing the best quality education and to produce Muslim, Mukmin, and Muhsin individuals who have a strong spirit and responsibility". This was affirmed by one of the founders of the school that:

The aim and purpose of the Pondok is to educate the Ummah towards being an ideal Muslim thinker who are knowledgeable, having good character, and tafaqqah fiddin.

Derived from this vision and mission, the Pondok Pesantren then generated five basic principles which become the pillars of students' character, they are:

(1) sincerity;

(2) modesty;

(3) independence;

(4) Islamic brotherhood; and

(5) freedom.

These were identified as the main pillars in developing students' character. The teacher interviews and students focus group also highlighted leadership and creativity as a significance character inculcated at the Pondok Pesantren. From the researchers observations character education at Pondok Pesantren Darunnajah is closely related to religion (Islam) guided by the Qur'an, Hadiths, and examples from prominent Muslim scholars. Character itself was seen to be the fruit of believing in Allah and its manifestation through Ibadah and doing good things. Some of these findings are similar with Lukens-Bull's (2005) research on teaching morality in Javanese Islamic education, in which he describes values such as selflessness, modesty, and self-sufficiency as central to all aspects of Pesantren life. For instance, communal sholat (prayer) which is required in 
METJ

6,2

82
Pondok Pesantren teaches the character of sisterhood and brotherhood. Modesty and sincerity are taught by a communal living arrangement and lifestyle. And the character of independence is reflected on the way the students taking care of their own basic needs such as housekeeping, managing their expenses, and solving day-to-day issues.

\section{The implementation of character education}

The findings are mapped to the implementation of character education at Pondok Pesantren Darunnajah. Data from the teacher interviews, student focus groups, observations, and supporting documents suggest that Pondok Pesantren Darunnajah adopts the comprehensive approach of character education based on Islamic values as its philosophy, its vision, mission, and basic principles of character. The results coalesce around three themes:

(1) knowledge;

(2) conditional; and

(3) practices.

The researcher grouped the findings into three main thematic areas reflecting what emerged from the fieldwork. This is also supported by the theory of character development that involves cognition, affect, as well as action to form habit (Ahmed, 1970; Ryan and Lickona, 1992) (Table I).

i. Knowledge (cognition). The first method of implementation of character education at Pondok Pesantren Darunnajah involves formal subjects containing character ( $a k h l a q)$ contents. Although there is no specific program designed exclusively on character education, the teachers and students suggest that many subjects are aimed to educate character such as Islamic theology (Aqidah akhlaq), Qur'an, Hadith, Fiqh, Mahfuzhat,

\begin{tabular}{|c|c|c|}
\hline & Themes & Sub-themes \\
\hline $\begin{array}{l}\text { Methods of implementation of character } \\
\text { education at Pondok Pesantren Darunnajah }\end{array}$ & $\begin{array}{l}\text { Conditional } \\
\text { Practices }\end{array}$ & $\begin{array}{l}\text { Formal subjects (curriculum) } \\
\text { Within curriculum } \\
\text { Speeches from Kyai and teachers } \\
\text { Reading material with character (akhlaq) } \\
\text { content } \\
\text { Visual display with character (akhlaq) } \\
\text { content } \\
\text { Character ( } a k h l a q) \text { commentary and } \\
\text { reminders } \\
\text { Modeling } \\
\text { Pondok Pesantren culture } \\
\text { Pondok Pesantren rules and regulations } \\
\text { Pondok Pesantren events and ceremonies } \\
\text { Family positive involvement } \\
\text { Ibadah } \\
\text { Extracurricular activities } \\
\text { Organization } \\
\text { Pondok Pesantren lifestyle } \\
\text { Daily routine } \\
\text { Social activity }\end{array}$ \\
\hline
\end{tabular}

Table I.

Summary of the analysis of teachers' interviews and students' focus group discussion 
Muthala'ah, Ushuluddin, The stories of the Companions (Shirah Nabawi), Leadership, Guidance for women (Nisaaiyyah), Guidance and counselling, and Education (Tarbiyah). Those subjects taught in the classroom as part of the curriculum. The other methods of character education are reflected from how and what values the teachers share with students in the classroom (within curriculum), speeches from Kyai and teachers, reading material and visual display with character (akhlaq) content, as well as character (akhlaq) commentary and reminders. Students affirmed that they gain valuable knowledge on good character (akhlaq), what is right and wrong, and how to be a good person (Muslim/ah) through those methods.

ii. Conditional (affective). To provide supportive conditional aspect of educating character, teachers and students of Pondok Pesantren Darunnajah said that the most important and effective method in developing character is by setting good example or role model either from Kyai (director), teachers, staffs, or even every person involved or worked at the Pondok Pesantren. The other methods such as environment, culture, rules, and regulations, and events and ceremonies held at Pondok Pesantren Darunnajah are also significance methods as they provide positive and supportive conditions to initiate the feelings to resolve, determination, and urge to practice of what they know (character). In addition, family positive involvement is may also strengthened it by giving support the positive conditions and habits at home.

iii. Practices (action). Majority of teachers agreed that Ibadah is the most essential method in educating character of Muslim students as acknowledged by Basher (1982) that the establishment of Ibadah or the practical duties of Islam should be included in the process of educating individuals to attain the goodness of character. Thus, it affirms that Islamic educational institutions have to provide a positive way that enable Muslim youth to attain good character, which called as Tarbiyah Rabbaniyah or Divine education. All teachers and students affirmed that Pondok Pesantren Darunnajah has a range of extracurricular activities for students, organization, and community groups. More so the lifestyle and daily routine are the significant methods in educating students' character. In fact, almost every aspect of life in the Pondok Pesantren is rooted on how to develop good character of students and allow students to learn, practice, and become part of their life. A senior teachers explained:

All activities in this Pondok Pesantren is aimed to educate students' character or (akhlaqul karimah).

\section{Factors contributing to the implementation of character education}

The findings show that all teachers and students agreed that the personality and character of Kyai (director), teachers, friends, and staffs (administrative) with whom students live and interact with are the most influential factor to develop students' character. Whereas, most of the interviewers also believed that Pondok Pesantren's environment, rules and regulations, the involvement in extracurricular activities, the impact of media, as well as parental involvement and encouragement of positive habits are contributing to the effectiveness of the implementation of character education at Pondok Pesantren Darunnajah.

\section{Conclusion}

The majority of teachers and students said that the Pondok Pesantren Darunnajah educates students' character, in many ways, to develop them as young Muslim

\section{Implementation of character education}

83 
METJ

6,2

84 generations and prepare them for their future life. Pondok Pesantren Darunnajah adopts comprehensive approach of character education based on Islamic values as its ultimate philosophy, its vision, mission, basic principles of character, as well as other main characters that developed and strengthened through three methods of implementation of character education:

(1) knowledge;

(2) conditional; and

(3) practice.

The character itself cannot be built in a time but it continues to be a comprehensive process, and the most effective model to implementation is through a comprehensive approach that integrates all aspects of school life as Berkowitz (2005) argued that effective character education is a transformation of culture and life of the school. However, this approach or model should also have control and evaluation to ensure the effectiveness of the methods, consistency of the people involved, and its positive implication on students' character.

\section{References}

Abdullah Syukri Zarkasyi, K.H. (2005), Gontor dan pembaharuan pendidikan pesantren, Grafindo Persada, PT, Jakarta.

Ahmed, K. (1970), "Some aspects of character building", available at: www.salaam.co.uk/ knowledge/aspects.php (accessed January 12, 2010).

Annisa Mutia (2010), "Pesantren sukses bangun karakter" ("Pesantren succeeds in building character"), Republika, 13 December.

Basher, M.O.H. Dr (1982), Islamic Moral Education: An Introduction, Umm Al-Qura University, Makkah Almukarramah.

Bauer, R.W. (1991), "Correlates of student character development in a small high school", unpublished dissertation, The Graduate College of Bowling Green State University, Bowling Green, $\mathrm{OH}$.

Berkowitz, M. (2005), What Works in Character Education, available at: www.character.org/uploads/ PDFs/White_Papers/White_Paper_What_Works_Practitioner.pdf (accessed January 4, 2010).

Berkowitz, M. and Bier, M.C. (2005), What Works in Character Education?, Character Partnership, Washington, DC.

Chartier, A.M.C. (2007), "Teachers', students', and principals' perspectives on character: their moral reasoning and wisdom: case study at two best practice character schools", unpublished thesis, University of Toronto, Toronto.

Darunnajah (2004-2009), “Angket calon wali santri baru tahun 2004-2009”, unpublished document, Darunnajah Press, Jakarta.

Darunnajah (2010), Darunnajah Islamic Boarding School, Darunnajah Press, Jakarta (English version).

Denny, F.M. (1995), "Pesantren”, in Gibb, H.A.R. and Kramers, J.H. (Eds), The Encyclopaedia of Islam, Vol. VIII, E.J. Brill, Leiden.

Dhofier, Z. (1985), Tradisi Pesantren, Studi tentang Pandangan Hidup Kyai, LP3ES, Jakarta.

Dhofier, Z. (1999), The Pesantren Tradition: The Role of the Kyai in the Maintenance of Traditional Islam in Java, Program for Southeast Asian Studies, Temple, AZ. 
Directorate General of Islamic Education, Ministry of Religious Affairs of Indonesia (2009), "Wajah lain Pondok Pesantren” ("Another perspective of Pondok Pesantren”), available at: http://pendis.kemenag.go.id/index.php? $\mathrm{a}=$ artikel\&id2=pendis (accessed March 28, 2010).

Herdani, Y. (2010), "Pendidikan karakter sebagai pondasi peradaban bangsa" ("Character education as a foundation to build national civilization"), Departmen of Higher Learning, Ministry of National Education of Indonesia, available at: http://dikti.kemdiknas.go.id/ index.php?option=com_content\&view=article\&id=1540:pendidikan-karakter-sebagaipondasi-kesuksesan-peradaban-bangsa\&catid=143:berita-harian (accessed December 24, 2010).

Hilda Sabri Sulistyo (2010), "Membangun karakter dan budaya di sekolah" ("Building character and culture in school"), available at: http://web.bisnis.com/artikel/2id2749.html (accessed March 2, 2010).

Huitt, W. (2000), Moral and Character Development. Educational Psychology Interactive, Valdosta State University, Valdosta, GA, available at: http://chiron.valdosta.edu/whuitt/col/morchr/ morchr.html (accessed February 12, 2010).

Lickona, T., Schaps, E. and Lewis, C. (2003), CEP's Eleven Principles of Effective Character Education, Character Education Partnership, Washington, DC.

Lukens-Bull, R.A. (2005), Teaching Morality; Javanese Education in a Globalizing Era, University of North Florida, Jacksonville, FL, available at: www.uib.no/jais/v003ht/03-026047Lukens1.htm (accessed March 4, 2009).

Mastuhu (1994), Dinamika Sistem Pendidikan Pesantren: Suatu Kajian Tentang Unsur dan Nilai Sistem Pendidikan Pesantren, INIS, Jakarta.

Megawangi, R. (2007), Semua Berakar Pada Karakter, Lembaga Penerbit FE-UI, Jakarta.

Ministry of National Education (2003), Undang-undang sistem pendidikan nasional RI (The Act of the Republic of Indonesia on National Education System), available at: www.inherentdikti.net/files/sisdiknas.pdf (accessed August 1, 2010).

Nucci, L.P. and Narvaez, D. (Eds) (2008), Handbook of Moral and Character Education, Routledge, New York, NY.

Omar, M.N. (2003), Christian and Muslim Ethics, Dewan Bahasa dan Pustaka, Kuala Lumpur.

Qomar, M. (2005), Pesantren dari transformasi metodologi menuju demokratisasi institusi, Erlangga, Jakarta.

Ryan, K. and Lickona, T. (1992), Character Development in Schools \& Beyond, 2nd ed., The Council for Research in Values \& Philosophy, Washington, DC.

Wehr, H. (1976) in Cowan, J.M. (Ed.), Arabic-English dictionary: The Hans Wehr Dictionary of Modern Written Arabic, 3rd ed., Spoken Language Services, Inc, New York, NY.

Williams, D.D., Yanchar, S.C., Jensen, L.C. and Lewis, C. (2003), "Character education in a public high school: a multi-year inquiry into unified studies", Journal of Moral Education, Vol. 32 No. 2, pp. 3-33.

\section{Further reading}

Al-Ghazali, A.H. (2006), The Book of Religious Learnings, Vol. 3, Islamic Book Service, New Delhi, Ihya Ulum-Din. Maulana Fazlul Karim (trans).

Basmeih, S.A. (2007), Tafsir Ar-Rahman; Interpretation of the Meaning of the Qur'an, Department of Islamic Development Malaysia, Kuala Lumpur.

\section{Implementation of character education}


METJ

6,2

86
Bukhari, M.I.I. (2008), "Sahih al-Bukhari", Sahih al-Bukhari: Being the Tradition of Saying and Doings of the Prophet Muhammad as Narrated by His Companions, Vol. 8, Islamic Book Service, New Delhi, M.M. Khan (trans).

Jones, R. (2007), Loan-Words in Indonesian and Malay, KITLV Press, Leiden.
Corresponding author

Duna Izfanna can be contacted at: dunaizfanna@gmail.com 